Journal of Criminal Law/2011, Volume 75/Issue 3, June/Articles/Unfitness to Plead and the Vulnerable Defendant: An Examination of the Law Commission's Proposals for a New Capacity Test - JCL 75 (194)

Journal of Criminal Law

JCL 75 (194)

1 June 2011

\title{
Unfitness to Plead and the Vulnerable Defendant: An Examination of the Law Commission's Proposals for a New Capacity Test
}

\author{
An Examination of the Law Commission's Proposals for a New Capacity Test \\ Helen Howard \\ Senior Lecturer in Law, Teesside University; e-mail: H.A.Howard@tees.ac.uk. The writer is grateful to Mike \\ Bowen for his insightful comments on an earlier draft. \\ (C) Vathek Publishing, 2011
}

\begin{abstract}
The Law Commission published Consultation Paper No. 197 in October 2010 on unfitness to plead. Among the many issues to be covered were: an examination of the test for capacity which is narrower than the test for capacity under the Mental Capacity Act 2005; the scope of the trial of facts; and whether accident, mistake or self-defence could be raised as part of the defence in the context of unfitness to plead. This article will examine some of the proposals made in the Law Commission's Consultation Paper with particular focus on the meaning of capacity, along with the scope and limitations of the current law on unfitness to plead.
\end{abstract}

Keywords Unfitness to plead; Decision-making capacity, Law Commission Consultation Paper No. 197; Reform proposals; Pritchard test

We should be judged as a society by how we protect our vulnerable members--in particular, the young, the elderly, and the physically and mentally disadvantaged. Part of this protection must take the form of shielding certain vulnerable individuals from the criminal justice system, either from criminal proceedings or the punishment that follows. In pursuit of this goal, we have the doctrine of doli incapax, ${ }^{1}$ the law relating to fitness to plead, and the insanity defence. The vulnerable defendant who is of particular interest in this article is the paranoid schizophrenic who seriously injures a number of people after hearing voices telling him that they are possessed by the devil. Clearly, under the current insanity defence, ${ }^{2}$ no defence would be available to him, given that he understands the nature and quality of his act, i.e. that he is injuring human beings, and assuming that he understands that what he is doing is legally wrong. ${ }^{3}$

While such an individual is acting on the basis of an entirely different belief system to other human beings and, in the author's opinion, cannot be considered to be rational, ${ }^{4}$ such a defendant may also now be found fit to plead, even where it can be shown that he believed that to speak up might result in him being tried for witchcraft, that the judge and jury were inhabited by evil forces, and that he would be executed on being found guilty. 5

\section{The current law}

An individual who is found unfit to stand trial will not have to do so, 6 nor will he be punished. The question of fitness will depend on the defendant's ability to understand the difference between guilty and not guilty pleas, 
to follow the evidence in the proceedings, instruct counsel and challenge jurors, although he need not necessarily be able to act in his own best interests. ${ }^{7}$ A defendant will have the capacity to stand trial even where he believes there are 'evil influences ... thought to be present in the proceedings' 8 as apparently this would not affect the defendant's ability to conduct his defence. ${ }^{9}$

Since the Criminal Procedure (Insanity and Unfitness to Plead) Act 1991, a judge may find an accused is unfit to plead, while a jury 10 will still be required to decide on the evidence whether the defendant 'did the act or made the omission charged against him as the offence'. ${ }^{11}$ If the jury considers the defendant did not carry out the offence, it may acquit him and no further consequences will ensue. If, however, the jury finds he carried out the offence, the court may make a disposal as it would have done had there been a finding of insanity. This may range from a hospital order to an absolute discharge. ${ }^{12}$

The test for unfitness to plead dates back to the case of $R v$ Pritchard 13 which required that, to be unfit to plead, an accused needs to be unable to plead to the indictment, to understand the course of the proceedings, to challenge a juror and to understand the evidence. $R v$ Davies ${ }^{14}$ added the requirement that the accused must be unable to instruct counsel.

These requirements were developed in $R \vee M(J o h n)^{15}$ in which the trial judge set out the criteria, requiring the defendant to show an inability in respect of any one of the following: (1) understanding the charges; (2) deciding whether to plead guilty or not; (3) exercising his right to challenge jurors; (4) instructing solicitors and counsel; (5) following the course of proceedings; and (6) giving evidence in his own defence. 16

In the light of previous authorities, these directions were found on appeal to have been 'admirable'. ${ }^{17}$

\section{The capacity issue within the current law}

The rationale behind finding an individual unfit to plead is the requirement that everyone is entitled to a fair trial. A person who is unfit to plead will be unable to present his case for the defence adequately by, for example, instructing counsel and giving his own version of events. Thus, a trial of such a vulnerable defendant would become one-sided and may comprise largely of guesswork on the part of the defence.

Opinion differs as to what would constitute a fair trial where the defendant's fitness to plead is in issue. A trial may be 'fair' if it avoids an unsafe verdict. 18 This may or may not involve the defendant being able to participate fully in the proceedings. There may be occasions involving, for example, a schizophrenic man who breaks a shop window and is charged with criminal damage, where the defendant cannot fully participate, yet a safe verdict would still be reached in the proceedings, based on the clear available evidence, and such a verdict would be more expedient than drawing out issues of competency. ${ }^{19} \mathrm{An}$ alternative view, which it is submitted is to be preferred, is that a fair trial implies the defendant being able to take responsibility for his actions and being condemned as such. A criminal trial holds the defendant accountable and answerable for his actions. An individual who is unable to play a proper part in a criminal trial ought not to be held responsible as he cannot respond to the charges against him. ${ }^{20}$ On this account, the effect of a defendant being unfit to plead and therefore unfit to stand trial is to render him ineligible for blame and punishment. The trial must represent a two-way moral conversation between the defendant and the court. This cannot occur where the defendant is found unfit to plead.

The test for unfitness as it stands is inadequate. Empirical research suggests that findings of unfitness to plead are very rare. 21 The logical conclusion that can be drawn from this is that many mentally ill individuals are being tried when unfit to participate adequately in proceedings.

The Law Commission comments that 'at best, the criteria are not comprehensive and place a disproportionate emphasis on low intellectual ability. At worst, the criteria simply set too high a threshold for finding an accused to be unfit to plead and are inconsistent with the modern trial process' ${ }^{22}$ Further, the Law Commission points out that the test only covers 'extreme cases of a particular type (usually bearing on cognitive deficiency)' 23 and it does not take account of all the aspects of a trial, such as the ability to give evidence. 24 The Rogers et al. study was further employed by the Law Commission 25 for its criticism of, inter 
alia, the failure of the Pritchard test to address suggestibility; any reference being made to memory or decisional competence; as well as a failure to take into account psychosis or cultural background.

The recent case of Moyle 26 highlights the unfairness of the old capacity test in Pritchard. It has been suggested that even where a defendant can instruct counsel and understand criminal proceedings, 'his delusional behaviour may, nevertheless, impact on the ability to make decisions which are in his best interests'. 27 The decision by the Court of Appeal in Moyle that 'delusions as to the court's powers of sentence, or as to the objectivity of the court, or as to the evil influences which are thought to be present in the proceedings, do not necessarily require a finding that a person is unable to give instructions and to understand the proceedings' 28 runs so contrary to the notion of a fair trial as to be absurd. One of the factors taken into account by the court in making its decision was that the defendant was aware that the proceedings were serious, and that he was being tried for a serious offence, 29 while the court also acknowledged that his mental disorder 'might have affected his ability to appraise, believe, weigh up and validly use information relating to the legal proceedings'. 30 Furthermore, the Court of Appeal added that '[e]ven if, at times during the trial, the appellant was not acting in his own best interests, in the evidence and instructions he gave, that does not, in itself, create, or contribute to a finding of unfitness to plead'. ${ }^{31}$ Though this 'in itself' may be true, 32 the defendant was guided by the belief that if he had disclosed his beliefs at the time, he would have been hanged for witchcraft'. 33 While the Law Commission acknowledges that decisions need not be rational, such a belief should at least trigger an examination of capacity under the proposed test. 34

Taylor comments 35 that '[i]ntuitively one has to have doubts about the fitness of a defendant who believes the court to be under the influence of Satan, but on reflection this state of mind does not necessarily impinge upon an individual's ability to participate in proceedings and understand them'. Respectfully, it is hard to imagine how believing a court to be under the influence of Satan would not impinge on an individual's ability to participate in proceedings. It is suggested in this article that one measure of potential success of the proposed capacity test is whether a defendant such as Moyle might have been considered fit to stand trial.

\section{Mental Capacity Act 2005}

In the explanatory notes of the Mental Capacity Act 2005 it is stated that one of the purposes of the Act is 'to improve and clarify the decision-making process for people unable to make decisions for themselves'. ${ }^{36}$ The definition of capacity under the 2005 Act is far broader than that provided in Pritchard. According to s. 2(1), 'a person lacks capacity where he is unable to make a decision for himself ... because of an impairment of, or a disturbance in the functioning of, the mind or brain' (emphasis added). Such an impairment can be permanent or temporary. 37 This will cover temporary mental illness such as, for example, temporary paranoid delusions. There is an inability to make a decision where $D$ is unable, inter alia: '(a) to understand the information relevant to the decision, ... or (c) to use or weigh that information as part of the process of making the decision'. ${ }^{38}$ According to s. 3(4) the information relevant to a decision includes information about the reasonably foreseeable consequences of '(a) deciding one way or another, or (b) failing to make the decision'.

So, the paranoid schizophrenic who believes that evil influences are at work in relation to his trial, and who also believes that he will be executed for witchcraft could well be regarded as lacking capacity to make a decision for the purposes of the Mental Capacity Act 2005. Were the Act to be applied to the fitness to plead proceedings, a defendant could more easily be found unfit to plead because, for example, he may be unable to weigh whether or not to disclose potentially relevant information where he believes that to do so would be to disclose such information to Satan. It is accepted that a paranoid schizophrenic might choose to act this way. ${ }^{39}$ A court may make decisions, it appears, with regard to an individual's personal welfare, property and affairs under far less onerous conditions than those which go towards testing a defendant's fitness to plead.40 This cannot be right.

\section{The Law Commission Consultation Paper}

\section{The rationale}


The Law Commission criticises the disproportionate reliance on the cognitive ability of the defendant under the current law on unfitness to plead, and suggests a capacity-based test will be a less abstract concept, more focused on the defendant's 'capacity to do something or to perform the task of making a particular decision in relation to a particular set of circumstances'. 41

Crucial to the Law Commission's decision to introduce a capacity-based test seems to be its view that an incapacity to make decisions has the potential to cause injustice. This incapacity is demonstrated in $R v$ Erskine, 42 where the defendant chose to offer an inappropriate defence, even though diminished responsibility could have been clearly established. The very illness from which the defendant had been suffering prevented him from accessing the most appropriate defence for the illness.

The Law Commission further points out that the right to effective participation in a trial is underpinned by the European Convention of Human Rights. 43 In Stanford $v$ United Kingdom, 44 this right is 'implicit in the very notion of an adversarial procedure'. SC $v$ United Kingdom 45 further defined 'effective participation' as the ability of the defendant to understand the thrust of what is said in court; to follow what is said by prosecution witnesses; to give his version of events to his lawyer; to point out statements with which he disagrees; and finally to point out facts that should be used in his defence. All of these criteria point to 'active involvement on the part of the accused rather than just a passive presence'. 46

\section{The decision-making capacity test}

The decision-making capacity test is proposed in order to take on board the above factors. Given that it is not the Law Commission's preference for the test to be proportionate, i.e. dependent on the seriousness of the charge and complexity of proceedings, 47 the proposal is for a test which will assess decision-making capacity against 'the entire spectrum of trial decisions'. 48

The test proposed 49 is that an individual will lack capacity if unable:

(1) to understand the information relevant to the decisions that he or she will have to make in the course of his or her trial, 50

(2) to retain that information, 51

(3) to use or weigh that information as part of a decision-making process, 52 or

(4) to communicate his or her decisions. 53

Recognising the rights of the individual to self-determination, 54 it is not intended that the test will require an accused to make rational or wise decisions, 55 although a failure to do so may trigger an inquiry as to whether the accused has decision-making capacity.

In proposing the test, the Law Commission recognises the civil law's approach to capacity as being based on proportionality, i.e. different levels of capacity may be required depending upon the type of decision to be made. ${ }^{56}$ Although currently the Law Commission is not opting to apply a principle of proportionality to the criminal law, it has invited views on this issue. ${ }^{57}$ An alternative proposed by the Law Commission is to allow a judge to take into account the complexity of proceedings and gravity of outcome in the context of the accused's capacity to deal with these. 58

Two possible additions to the decision-making capacity test: special measures and the psychiatric test 
Special measures to assist or support vulnerable adults are already in existence, 59 but it is unlikely that they are employed as frequently as perhaps they ought to be. 60 In considering ways in which special measures for vulnerable adults can be brought to the forefront of a trial, the Law Commission proposes two possibilities. First, and preferred by the Law Commission, 61 the special measures can be used as part of the test to assist in assessing whether a person lacks the necessary decision-making capacity. Alternatively, once an individual is found to have the necessary capacity, the special measures may be used to assist the person who nevertheless requires additional support. 62

A psychiatric test is proposed in order to assess whether or not an accused has the necessary decision-making capacity. 63 To some degree, the introduction of such a test is unavoidable in the light of Article 5 of the European Convention on Human Rights. For the detention of persons of 'unsound mind', the opinion of two medical practitioners is required, one of whom must have expertise in the diagnosis or treatment of mental disorder. 64 The psychiatric test is also thought to be necessary due to psychiatrists having applied the Pritchard test inconsistently, although it is acknowledged that the inconsistencies may have arisen in part from the inadequacies of the existing law. 65

\section{Commentary}

It is accepted that a decision need not be rational or wise. So long as irrational decisions are able to trigger a need for assessment, then the proposal that a decision need not be rational will recognise the individual's right to self-determination. No one can say that a decision which appears rational to one person is necessarily a good decision in the eyes of another.

\section{The capacity test}

Support for a test based on decision-making competence can be found in the Jersey case of Attorney-General v O'Driscol/66 and also in Professor Mackay's commentary on this case.67 The Law Commission's proposals are undoubtedly an improvement on the current law. Parts (1), (2) and (4) of the decision-making capacity test do not appear to deviate as far from the current law as part (3). 68 In its current form, part (3) seems to be very broad, and open to interpretation. In the context of mental illness, the flexibility offered by this part of the test should mean that the test is open to many more mentally ill defendants, and that unfair trials should be avoided to a much greater degree.

However, could part (3) be open to abuse? Is there a danger that a defendant who has no recognised mental illness will try to claim an inability to use or weigh information as part of a decision-making process? Might such a provision allow an individual claiming stress, crippling shyness, overwhelming tiredness,

nervousness, or poor social background to escape a full trial? It may be that the proposal needs to be linked to some kind of identifiable mental illness. The proposed psychiatric test may remedy this issue to some degree. However, it may be worth adding the phrase to the test 'an individual will lack decision-making capacity if, due to mental or physical illness, whether temporary or permanent, he is unable ...'.

\section{Proportionality}

While it makes sense to assess an accused against the whole range of activities in which he may be required to participate during a trial, clearly some trials will be more straightforward than others. ${ }^{69}$ The difficulty here lies in measuring where the threshold for capacity should be set. If the threshold is too high, then some individuals may unfairly escape the criminal justice system. If it is too low, then some will be unfairly drawn into trials, where special measures cannot compensate for the lack of capacity. It seems that much will hinge on how the proposed psychiatric test is drafted and applied.

\section{Special measures}


With regard to the use of special measures forming part of the decision-making capacity test, there is merit in the argument that this would avoid special measures being overlooked at trial. 70 However, there could be a danger that an accused who lacks capacity may be 'pushed' into a trial, in which he is dependent on the special measures being adequately resourced. It is submitted that the special measures should be separate from the legal and psychiatric tests.

\section{Psychiatric test}

There is currently no set psychiatric test ${ }^{71}$ and existing psychiatric tests are criticised. ${ }^{72}$ The proposal that the test should assess decision-making capacity is concerning. The ultimate decision should lie with the court. Will a judge allow for the consideration of factors outside of the, as yet unwritten and untested, psychiatric test, or will he be exclusively guided by it? The danger here is that too much weight may be attached to the opinion of psychiatrists who will make the final decision as to whether an individual has the capacity to enter the criminal justice system. ${ }^{73}$ By contrast, the Law Commission provides the example of the proposed Scottish model based on 'effective participation' in a trial. ${ }^{74}$ This potential to admit evidence that falls outside of the experience of experts is rejected by the Law Commission on the grounds that 'the majority of cases ... concern conditions in relation to which psychiatric opinion is relevant'. 75 While it is accepted that the opinions of two medical practitioners are necessary, it is hoped that this will not exclude the possibility of evidence outside of the psychiatric remit where this would be useful. The test should merely 'assist in measuring the capacity of the accused' 76 and not usurp the position of the legal test.

\section{Conclusion}

In terms of the new legal capacity test, the Law Commission's proposals go a substantial way towards remedying the problems connected to the current law on unfitness to plead. With the caveat that the legal test should contain a reference to temporary or permanent physical or mental illness, and that there should be caution in creating an over-dependence on the psychiatric test, the proposed reforms deserve support. Most importantly, the paranoid schizophrenic who is hindered by his own psychosis from presenting and challenging evidence will be recognised as lacking the decision-making capacity to stand trial. Would the type of defendant in Moyle be found to lack decision-making capacity under part (3) of the proposed test? Given the Law Commission's example of a paranoid schizophrenic who believes the court is out to get him, 77 it is likely that he would. In the writer's opinion, such a test is a positive step towards the protection of vulnerable adults. It is to be hoped that the Law Commission proposals on insanity due this summer can be received with the same optimism.

1 Given the developments in the law of doli incapax, another area of concern relates to the emotionally immature young person who is above the age of criminal responsibility, but lacks the ability to comprehend the criminal proceedings being taken against him. It is not proposed that the doctrine and its overlap with unfitness to plead will be examined in this article.

2 M'Naghten Rules ((1843) 8 ER 718): (1) Every man is presumed to be sane until the contrary is proved; (2) It must be proved that, at the time of committing the act, $D$ was labouring under such a defect of reason from disease of the mind, as not to know the nature and quality of the act, or that it was wrong.

$3 \quad R v$ Windle [1952] 2 QB 826; $R$ v Johnson [2007] EWCA Crim 1978.

4 H. Howard, 'Reform of the Insanity Defence: Theoretical Issues' (2003) 67 JCL 51.

$5 \quad$ R v Moyle [2008] EWCA Crim 3059. 
6 Criminal Procedure (Insanity) Act 1964, ss 4 and 4A, as amended by the Criminal Procedure (Insanity and Unfitness to Plead) Act 1991.

$7 \quad R$ v Robertson [1968] 3 All ER 557.

$8 \quad R$ v Moyle [2009] Crim LR 586.

$9 \quad R$ v Moyle [2008] EWCA Crim 3059 at [38].

10 Criminal Procedure (Insanity) Act 1964, s. 4(5), as amended by the Domestic Violence, Crime and Victims Act 2004, s.

22.

11 Criminal Procedure (Insanity) Act 1964, s. 4A, as amended by the Criminal Procedure (Insanity and Unfitness to Plead) Act 1991.

12 Criminal Procedure (Insanity) Act 1964, s. 5, as amended by the Criminal Procedure (Insanity and Unfitness to Plead) Act 1991 and the Domestic Violence, Crime and Victims Act 2004.

13 (1836) 7 C \& P 303.

14 (1853) Car \& Kir 328.

15 [2003] EWCA Crim 3452. R v M (John) was discussed by the Law Commission (see Law Commission, Unfitness to Plead, Consultation Paper No. 197 (October 2010) paras 2.52-2.59).

16 Further, it is irrelevant that a defendant has a low mental age, so long as he can explain to his lawyers his version of events and disagree with statements made (SC v United Kingdom [2005] 1 FCR 347.

$17 R$ V M (John) [2003] EWCA Crim 3452 at [31].

18 D. Grubin, 'What Constitutes Fitness to Plead?' [1993] Crim LR 748, 757.

19 D. Grubin, 'Fitness to Plead and Fair Trials: (2) A Reply' [1994] Crim LR 423 at 424.

20 R. A. Duff, 'Fitness to Plead and Fair Trials: (1) A Challenge' [1994] Crim LR 419 at 420-1.

21 Law Commission, Unfitness to Plead, Consultation Paper No. 197 (October 2010) para. 2.60. Studies cited include T. P. Rogers, N. J. Blackwood, F. Farham, G. J. Pickup and M. J. Watts, 'Reformulating Fitness to Plead: a Qualitative Study' (2009) 20(6) Journal of Forensic Psychiatry and Psychology 815.

22 Law Commission, above n. 21 at para. 2.43.

23 Not unlike the failure of the M'Naghten Rules to address a failure in rationality other than the cognitive. For a more detailed commentary on the disproportionate emphasis on cognitive ability, see Law Commission, above n. 21 at para. 2.69.

24 Law Commission, above n. 21 at para. 2.47.

25

Ibid. at para. 2.65 . 
$27 R$ v Moyle (Peter Geoffrey) (2009) 73 JCL 196L, case note by L. Madhloom, 'Unfit to Plead and Diminished Responsibility'.

$28 \quad R$ v Moyle [2008] EWCA Crim 3059 at [38].

29 Ibid. at $[39(\mathrm{c})]$.

30 Ibid. at [27].

31 Above n. 28 at $[39(h)]$.

32 See also $R$ v Robertson [1968] 1 WLR 1767.

$33 R$ v Moyle [2008] EWCA Crim 30 at [27], per Dr McKenna's medical evidence.

34 Discussed below at n. 52.

$35 R$ v Moyle (Peter Geoffrey) [2009] Crim LR 586 at 588, comment by N. Taylor, 'Fitness to Plead--Whether Paranoid Delusions May Render Accused Unfit to Plead'.

36 Mental Capacity Act 2005, explanatory notes, available at $\underline{h t t p: / / w w w . l e g i s l a t i o n . g o v . u k / u k p g a / 2005 / 9 / n o t e s / c o n t e n t s}$, accessed 21 March 2011.

37 Mental Capacity Act 2005, s. 2(2).

38 Mental Capacity Act 2005, s. 3(1), emphasis added.

$39 \quad R$ v Moyle [2008] EWCA Crim 3059 at [28].

40 Mental Capacity Act 2005, s. 16.

41 Law Commission, above n. 21 at para. 2.73.

42 [2009] EWCA Crim 1425. See Law Commission, above n. 21 at paras 2.75-2.77.

43 Articles 5 and 6.

44 Application No. 24724/90 at [26]. Extended in T v United Kingdom; $V$ v United Kingdom (2000) 30 EHRR 121.

45 (2005) 40 EHRR 10 at [29].

46 Law Commission, above n. 21 at para 2.102.

47 Above n. 46 at para. 3.83. 
50 For example, an individual with low cognitive ability (Law Commission, above n._21 at para. 3.15).

51 For example, an individual who is severely depressed with disturbed sleep pattern who is unable to remember things (Law Commission, above n. 21 at para. 3.16).

52 For example, the individual with ADHD who is impulsive and cannot focus (Law Commission, above n. 21 at para. 3.17); the paranoid schizophrenic who believes the court is out to get him (Law Commission, above n. 21 at para. 3.18).

53 For example, the autistic individual who is unable to communicate with others (Law Commission, above n. 21 at para. 3.20).

54 Law Commission, above n. 21 at para. 3.47.

55 Ibid. at paras 3.54 and 3.57 .

56 Law Commission, above n. 21 at paras 3.7-3.8. 'Gravity ... is measured by reference to implications and consequences' (ibid. at para. 3.9).

57 Provisional Proposal 4, ibid. at para. 1.34.

58 Ibid. at para. 3.101.

59 Practice Direction (Criminal Proceedings: Consolidation) [2002] 1 WLR 2870, para. III.30, as inserted by Practice Direction (Criminal Proceedings: Further Directions) [2007] 1 WLR 1790.

60 Law Commission, above n. 21 at paras 4.12 and 4.20

61 Above n. 60 at para. 4.19.

62 Ibid. at para. 4.1.

63 Ibid. at para. 5.4

64 Ibid. at para. 5.5, referring to Winterwerp v Netherlands (1979) 2 EHRR 387 at [39].

65 Law Commission, above n. 21 at para. 5.14.

66 Attorney-General v O'Driscoll (No. 2) [2003] JRC 117, Royal Ct (Jer).

67 R. D. Mackay, 'On Being Insane in Jersey: Part 3--The Case of Attorney General v O'Driscoll' [2004] Crim LR 219.

68 See above and Law Commission, above n. 21 at para. 3.13.

69 See G. Scott-Moncrieff and L. Vassall-Adams, 'Yawning Gap: Capacity and Fitness to Plead', Counsel, October 2006, 14, 
15 (cited in Law Commission, above n. 21 at para. 3.83).

70 Law Commission, above n. 21 at para. 4.20 .

71 Ibid. at para. 5.2 .

72 Ibid. at para. 5.3 .

73 Although, ironically, had the Court of Appeal in Moyle followed the views of medical opinion, the harsh outcome of this case may have been avoided.

74 Law Commission, above n. 21 at paras 5.24-5.28.

75 Above n. 74 at para. 5.36.

76 Ibid. at para. 5.39.

77 Ibid. at para. 3.18. 